Jurnal Simbolika: Research and Learning in Communication Study, 4 (2) Oktober 2018

ISSN 2442-9198 (Print), ISSN 2442-9996 (Online)

DOI: http://dx.doi.org/10.31289/simbollika.v4i2.1832

\title{
Model Komunikasi Antarpribadi Orang Dengan HIV/AIDS dalam Menghadapi Stigma dan Diskriminasi Lingkungan Sosial
}

\section{Interpersonal Communication Model of People Living With HIV/AIDS in Facing of Stigma and Social Environmental Discrimination}

\author{
Dwianita* \\ Magister Ilmu Komunikasi, Fakultas Ilmu Sosial dan Ilmu Politik \\ Universitas Sumatera Utara, Indonesia
}

*Coresponding Email: dwianitaaa@gmail.com

\begin{abstract}
Abstrak
Tujuan penelitian ini adalah untuk menganalisis komunikasi antarpribadi, hambatan komunikasi, serta menemukan model komunikasi antarpribadi ODHA dalam menghadapi stigma dan diskriminasi lingkungan sosial dengan menggunakan Teori Komunikasi Antarpribadi, Pengungkapan Diri, Teori Tindakan Beralasan, dan Teori Disonansi Kognitif. Penelitian dilakukan di Pusat Pelayanan Khusus, RSUP H. Adam Malik Medan. Penelitian ini menggunakan metode kualitatif dan studi kasus. Informan dalam penelitian ini adalah ODHA, teman, keluarga, konselor, perawat, dan masyarakat. Adapun metode pengumpulan data dilakukan melalui wawancara mendalam dan observasi. Hasil penelitian menunjukkan bahwa komunikasi antarpribadi ODHA dalam penyampaian informasi status diri masih memperoleh stigma dan diskriminasi dari lingkungan sosial berupa penolakan, pengusiran, pengucilan, jibiran, dan ekspresi wajah yang kurang menyenangkan.
\end{abstract}

Kata Kunci: Model Komunikasi, Stigma, Diskriminasi, Rumah Sakit Adam Malik.

\begin{abstract}
The purpose of this study was to analyse the interpersonal communication, communication barriers, and find a model of interpersonal communication of PLWHA in facing of stigma and social environmental discrimination used Interpersonal Communication Theory, Self Disclosure, Theory of Reasoned Action, and Cognitive Dissonance Theory. The study was conducted at Special Service Center, H. Adam Malik General Hospital Medan. This study uses qualitative method and case study. Informants in this study were PLWHA, friend, family, counselor, nurse, and society. The data was collected through in depth interview and observation. The results showed that interpersonal communication by PLWHA in delivering their status information still received stigma and discrimination from social environment such as refusal, eviction, exclusion, contempt, and unpleasant facial expression.
\end{abstract}

Keywords: Communication model, Stigma, Discrimination, Adam Malik Hospital.

How to Cite: Dwianita. (2018). Model Komunikasi Antarpribadi Orang Dengan HIV/AIDS dalam Menghadapi Stigma dan Diskriminasi Lingkungan Sosial. Jurnal Simbolika: Research and Learning in Communication Study. 4 (1): 140-159. 


\section{PENDAHULUAN}

Manusia pada dasarnya adalah makhluk sosial yang membutuhkan komunikasi dengan lingkungannya. Setiap individu membutuhkan orang lain dalam hal memenuhi kebutuhannya melalui interaksi dengan orang lain. Hal ini juga dialami oleh Orang Dengan HIV/AIDS (ODHA) melalui komunikasi antarpribadi dalam berinteraksi dengan lingkungan sosialnya.

Masalah sosial yang dialami ODHA disebabkan adanya stigma di masyarakat. Stigma yang menganggap bahwa orang yang terinfeksi HIV/AIDS adalah orang yang menyimpang akibat prilaku negatif yang tidak sesuai dengan norma yang berlaku di masyarakat seperti perilaku seksualitas, berganti pasangan, dan menggunakan narkoba. Akibat keterbatasan pengetahuan, masyarakat juga menganggap bahwa HIV/AIDS sebagai sesuatu yang berbahaya dan mematikan.

Stigma tersebut membuat terasingnya mereka dengan munculnya perlakuan diskriminasi terhadap para ODHA. Secara umum perlakuan diskriminasi yang diterima ODHA tidak diterimanya mereka dengan cara diusir, dijauhi, membedakan peralatan makanan, ditolak pada pelayanan kesehatan, dan diskriminasi secara verbal berupa sindiran dan hinaan.
Bentuk diskriminasi terhadap ODHA juga dipaparkan oleh (Gaudine, Gien, Thuan, \& Dung, 2010) meliputi penghindaran kontak mata, berdiri jauh ketika sedang diajak berbicara, tidak duduk di tempat yang sama dengan ODHA, tidak mau bersentuhan, penggunaan toilet secara terpisah, serta tidak membeli produk yang dijual oleh ODHA. Adanya stigma dan diskriminasi menyebabkan ODHA merasa kesulitan untuk membuka status kesehatannya kepada orang lain.

Stigma mengenai penyakit HIV/AIDS yang mengarah pada ODHA menjadi hambatan komunikasi dalam melakukan proses-proses sosial. Mereka akan membatasi interaksi dengan lingkungan sosialnya karena khawatir akan reaksi penerimaan dirinya. Stigma disebabkan oleh banyak faktor antara lain kurangnya pemahaman masyarakat mengenai HIV/AIDS. Ketidaktahuan masyarakat tentang bagaimana HIV ditularkan termasuk anggapan bahwa HIV/AIDS disebabkan pada orang yang melakukan perbuatan menyimpang. Sehingga pada umumnya masyarakat cenderung menghindari dan menjauhi kontak sosial dengan ODHA.

Komunikasi antarpribadi ODHA dilakukan dengan ketidakterbukaan mengenai status kesehatannya akibat rasa takut akan stigma dan diskriminasi dari 
lingkungan sosial. Ketidakterbukaan ini juga dipengaruhi oleh jarak atau kedekatannya dengan orang lain. Selama proses komunikasi antarpribadi berlangsung terjadinya interaksi mengenai berbagai informasi dan perasaan dengan orang lain untuk saling membuka diri sangat penting. Dalam hal ini komunikasi antarpribadi belum sepenuhnya terjalin dengan baik dikarenakan ODHA tidak memberikan informasi mengenai status dirinya kecuali kepada orang-orang terdekatnya saja. Penyembunyian status kesehatan mereka merupakan komunikasi yang mereka lakukan dimasyarakat. Kesulitan akan keterbukaan tentang status ODHA itu sendiri kepada lingkungan sosialnya dilakukan untuk melindungi diri dari tanggapan buruk terhadap ODHA.

Sesuai dengan pernyataan Hemawati (dalam Suriana \& Dewi, 2013) bahwa banyaknya masyarakat yang beranggapan negatif terhadap korban HIV/AIDS sehingga ODHA cenderung menutup diri dari lingkungan masyarakat dan hanya mau berbagi mengenai dirinya dengan orang-orang tertentu. Mereka merasa lebih nyaman untuk tinggal sendiri atau bersama dengan orang-orang yang menderita penyakit yang sama dengan mereka. Hal itu menunjukkan adanya kecemasan akan diskriminasi yang dihadapi oleh penderita HIV/AIDS.
Keadaan ini semakin terlihat pada perilaku menyembunyikan status penyakitnya dari orang-orang disekitarnya demi menjaga hubungan yang wajar dengan mereka.

Melalui penerapan model komunikasi dalam menghadapi stigma dan diskriminasi, terkadang ODHA sebagai komunikator tidak dapat menyampaikan pesannya dengan baik karena lingkungan sosialnya belum memahami dan menerima apa yang disampaikan ODHA disebabkan adanya berbagai kendala yang terjadi dalam komunikasi. Kendala tersebut dapat dihilangkan atau diminimalisir jika komunikator dapat menganalisis reaksi yang ditimbulkan oleh komunikan.

Stigma dan diskriminasi akan mempengaruhi cara pandang ODHA terhadap dirinya termasuk konsep dirinya. Konsep diri yang positif akan mendukung komunikasi antarpribadi, sebaliknya konsep diri yang negatif akan menghambat proses komunikasi yang terjadi. ODHA yang mengalami stigma dan diskriminasi akan memiliki konsep diri yang negatif dengan tidak melakukan berbagai upaya agar membuat mereka dapat diterima oleh lingkungan sosialnya.

Indonesia merupakan salah satu negara di Asia dengan epidemi HIV/AIDS yang berkembang cepat. Data dari Ditjen Pencegahan dan Pengendalian Penyakit (P2P) Kementerian Kesehatan RI 
menyatakan situasi kasus HIV/AIDS terjadi peningkatan setiap tahunnya, untuk kasus HIV sampai dengan tahun 2010 dilaporkan sebanyak 21.591, tahun 2011 sebanyak 21.031, di tahun 2012 sebanyak 21.511, tahun 2013 tercatat 29.037, pada tahun 2014 sebanyak 32.711, meningkat di tahun 2015 sebanyak 30.935, dan terus meningkat sampai tahun 2016 yang dilaporkan sebanyak 41.250. Sedangkan data untuk kasus AIDS sampai dengan tahun 2010 dilaporkan sebanyak 7.470, tahun 2011 sebanyak 8.279, pada tahun 2012 menjadi 10.862, tahun 2013 meningkat menjadi 11.741, terjadi penurunan tahun 2014 sebanyak 7.963, turun kembali tahun 2015 sebanyak 7.185, dan kembali meningkat di tahun 2016 yang dilaporkan sebanyak 7.491 (Kemenkes RI, 2017).

Kementerian Kesehatan RI (2017) menyatakan bahwa Provinsi Sumatera Utara menempati posisi ketujuh setelah Provinsi Jakarta, Jawa Timur, Papua, Jawa Barat, Jawa Tengah, dan Bali dengan jumlah infeksi HIV yang dilaporkan dari tahun 2009 sampai dengan Maret 2017 sebesar 13.454 kasus dan AIDS yaitu sebesar 3.879 kasus. Hal ini menunjukkan bahwa kasus HIV/AIDS di Provinsi Sumatera Utara masih cukup tinggi.

Berangkat dari permasalahan di atas, berbagai upaya telah dilakukan pemerintah dalam mengurangi penyebaran HIV/AIDS. Khusus untuk Provinsi Sumatera Utara tercantum pada Peraturan Daerah (Perda) Kota Medan No. 01 Tahun 2012 Pasal 1 (22) tentang Pencegahan dan Penanggulangan HIV dan AIDS. Upaya-upaya itu dilakukan dengan cara menyediakan layanan yang mendukung penanggulangan epidemi HIV/AIDS seperti pendidikan sebaya, pelayanan kesehatan dasar, perawatan dan pengobatan HIV dan AIDS, penjangkauan, konseling, dan Voluntary Conselling and Testing (VCT) yang ditujukan untuk mencegah dan mengurangi resiko penularan HIV serta mengurangi dampak sosial ekonomi akibat HIV/AIDS pada individu, keluarga, dan masyarakat.

Berdasarkan Keputusan Menteri $\begin{array}{lll}\text { Kesehatan } & \text { RI }\end{array}$ 782/Menkes/SK/IV/2011 tentang rumah sakit rujukan sebagai akses pelayanan bagi para ODHA, dimana salah satunya bisa di dapatkan di Rumah Sakit Umum Pusat Haji Adam Malik (RSUP HAM) Medan. Berdasarkan hasil observasi awal yang dilakukan di Pusat Pelayanan Khusus (Pusyansus) RSUP H. Adam Malik, jumlah kasus pasien HIV yang pernah masuk perawatan juga terjadi peningkatan dari tahun ke tahun. Peningkatan di mulai dari tahun 2005 sampai dengan tahun 2015 dilaporkan sebanyak 4.931 kasus, sampai 
tahun 2016 sebanyak 5.083 kasus, tahun 2017 sebanyak 5.362 kasus dan hingga sampai Mei 2018 dilaporkan sebanyak 5.518 kasus. RSUP H. Adam Malik sudah menangani pasien HIV/AIDS dengan memberikan akses pelayanan sebagai mediator antara masyarakat yang negatif HIV/AIDS dan yang menyandang status sebagai ODHA.

Hingga saat ini masih banyak ODHA yang menerima diskriminasi dari lingkungan sosial. Mengutip dari artikel Liputan6 pada Desember 2016, seorang ODHA bernama Hana yang memiliki profesi sebagai pekerja seks sekaligus waria yang ikut menjalani tes HIV. Setelah keluarga mengetahui Hana positif HIV, diskriminasi langsung ia dapat dari dalam rumahnya. Segala perlengkapan makan dan mandi dipisahkan tersendiri. Begitu juga dengan kasus Liana yang juga seorang pekerja seks dan mengalami diskriminasi serupa. Sikap kedua orang tuanya berubah drastis dan berfikir HIV merupakan aib keluarga serta penyakit yang memalukan (Liputan6.com)

Roey (2003:10) menyatakan bahwa diskriminasi bisa terjadi dalam berbagai bentuk, dari yang hampir tak terlihat sampai yang terlihat seperti kekerasan fisik. Begitupun ketakutan ODHA dapat muncul dari persepsi yang tidak selalu benar mengenai HIV/AIDS sampai kepada diskriminasi dalam bentuk penolakan dan kekerasan yang bersifat objektif.

Diskriminasi terhadap ODHA sangat berpengaruh dalam upaya penerimaan dirinya di masyarakat termasuk bagaimana tanggapan masyarakat mengenai keberadaan mereka dalam kehidupan sosial. Sebagaimana Wood (2013:158) menyatakan dalam berkomunikasi dengan lingkungan sosial, kita akan membutuhkan konfirmasi dari orang lain, yaitu pengakuan berupa tanggapan dari orang lain dan diskonfirmasi, yaitu penolakan berupa tanggapan yang menunjukkan tidak mengakui keberadaan orang lain. Pengakuan tersebut tidak hanya berupa keberadaan orang lain tetapi pengakuan mengenai apa yang orang lain rasakan, pikirkan atau katakan.

Berkaitan dengan hal tersebut, ODHA mendapat diskonfirmasi dari orang lain dengan tidak diakuinya mereka di tengah masyarakat akibat adanya stigma negatif sampai diskriminasi yang mereka terima. Sampai saat ini sebagian besar ODHA belum berani melakukan pendekatan secara antarpribadi melalui komunikasi dengan masyarakat dan berusaha untuk menutupi status diri sebagai ODHA di lingkungan sosialnya.

Penelitian ini dianggap penting untuk diteliti karena berkaitan dengan beberapa 
aspek. Pertama, stigma dan diskriminasi masih menjadi faktor penghambat dalam pengungkapan diri ODHA. Kedua, Dinamika komunikasi antarpribadi diharapkan dapat mengurangi stigma dan diskriminasi berkaitan dalam upaya penerimaan dirinya di masyarakat. Berdasarkan uraian diatas, peneliti tertarik untuk meneliti Model Komunikasi Antarpribadi Orang Dengan HIV/AIDS (ODHA) dalam Menghadapi Stigma dan Diskriminasi Lingkungan Sosial. Adapun pemilihan lokasi penelitian ini dipilih karena, pertama, RSUP H. Adam malik adalah salah satu rumah sakit yang memiliki klinik VCT pertama di kota Medan. Kedua, RSUP H. Adam Malik berdasarkan SK Menkes RI No. HK.02.02/MENKES/390/2014 ditetapkan sebagai Rumah Sakit Rujukan Nasional dan merupakan Rumah Sakit Umum Kelas A.

Wimmer dan Dominick (dalam Kriyantono, 2014) menyatakan paradigma adalah bagaimana peneliti melihat dunia meyakini tentang seperangkat teori, prosedur, dan asumsi. Paradigma dalam suatu penelitian adalah seperangkat cara pandang yang luas dan menjadi konsep utama dalam suatu penelitian yang akan memandu kegiatan atau proses dari penelitian tersebut.

Penelitian ini menggunakan paradigma konstruktivisme untuk melihat komunikasi antarpribadi Orang Dengan HIV/AIDS (ODHA) dalam menghadapi stigma dan diskriminasi lingkungan sosial. Tindakan objek penelitan ditentukan oleh konstruksi diri sekaligus konstruksi lingkungan luar dari diri melalui proses panjang sejumlah pengalaman.

Mulyana (2006) menyatakan komunikasi antarpribadi adalah komunikasi antara orang-orang secara tatap muka yang memberikan kemungkinan setiap pesertanya merespon reaksi orang lain secara langsung, baik secara verbal maupun nonverbal. Bungin (2013:32) memperjelas bahwa komunikasi antarpribadi adalah komunikasi antar individu yang bersifat pribadi baik yang terjadi secara langsung (tanpa perantara) maupun tidak langsung (melalui perantara) seperti kegiatan percakapan secara tatap muka atau melalui media. Fokus pengamatannya adalah bentukbentuk dan sifat hubungan (relationship), percakapan (discourse), interaksi dan karakteristik komunikator.

Berdasarkan Theory of Reasoned Action (TRA)/Tindakan beralasan oleh Martin Fishbein dan Icek Ajzen (dalam Jogiyanto, 2007) menyatakan teori ini menghubungkan antara keyakinan (belief), sikap (attitude), kehendak (intention), dan perilaku (behavior). Kehendak merupakan faktor dari perilaku, artinya jika ingin 
mengetahui apa yang akan dilakukan seseorang, cara terbaik adalah mengetahui kehendak orang tersebut. Tetapi seseorang dapat membuat pertimbangan berdasarkan alasan-alasan yang sama sekali berbeda atau tidak selalu berdasarkan kehendak. Konsep penting dalam teori ini adalah fokus perhatian (salience), yaitu mempertimbangkan sesuatu yang dianggap penting. Dan kehendak (intention) ditentukan oleh sikap dan norma subyektif.

Lebih lanjut Littlejohn (2011) menyatakan teori ini berdasarkan dari perilaku ditentukan oleh sikap seseorang terhadap perilaku dan kumpulan keyakinan tentang bagaimana orang lain ingin seseorang berperilaku. Miller (2001) TRA digunakan untuk melihat bagaimana individu akan berperilaku berdasarkan sikap dan perilaku yang sudah ada sebelumnya. Keputusan individu untuk terlibat dalam perilaku tertentu didasarkan pada hasil yang nantinya akan diharapkan individu tersebut.

Secara lebih sederhana, teori ini mengatakan bahwa seseorang akan melakukan suatu perbuatan apabila ia memandang perbuatan itu positif dan bila ia percaya bahwa orang lain ingin agar ia melakukannya. Bagi ODHA, mereka akan melakukan suatu perbuatan yang ia yakinin akan menimbulkan efek positif jika melakuannya seperti menyembunyikan status HIV kepada orang lain dengan alasan terhindar dari stigma dan diskriminasi.

Sedangkan Teori Disonansi Kognitif menurut Festinger (dalam Effendy, 2003) berarti ketidaksesuaian antara kognisi aspek sikap dengan perilaku yang terjadi pada diri seseorang. Setiap orang yang mengalami disonansi akan berupaya mencari cara untuk mengurangi disonansinya.

Menurut Festinger (dalam Surip, 2011), Seseorang dimotivasi untuk mengurangi ketidakpastian sebanyak mungkin, bahkan bila perlu mengubah sikap yang diyakininya. Disonansi kognitif merupakan bentuk teknik pembelaan diri (self defense technique) yang dilakukan oleh seseorang untuk memperoleh harga diri (self esteem). Seseorang harus memiliki kemampuan menempatkan diri dengan berbagai pilihan dan kemungkinan yang terjadi.

Hutagalung (2015) menyatakan terdapat dua hal yang mengatur teori disonansi yaitu, pertama, disonansi akan menciptakan tekanan diri yang mendorong individu untuk berubah. Kedua, ketika disonansi muncul, individu tidak hanya akan menyaringnya namun juga menghindari dari situasi agar disonansi lanjutan tidak muncul. 
Teori disonansi kognitif termasuk dalam cakupan komunikasi antarpribadi. Dimana disonansi kognitif menimbulkan hubungan yang tidak sesuai yang akan menimbulkan terjadinya hambatan sehingga akan mendorong untuk mengurangi disonansi tersebut. Dorongan itu terwujud pada perubahan pada kognisi, perubahan tingkah laku, dan menghadapkan diri pada beberapa informasi dan pendapat-pendapat baru yang sudah diseleksi terlebih dahulu (Sarwono, 2004).

Akibat disonansi kognitif adalah ketidaknyamanan psikologis pada orangorang disekitarnya. Pada ODHA ketidaknyamanan ini dapat berbentuk perasaan malu, takut, cemas dan sebagainya. Adanya unsur kognisi berupa pengetahuan, pendapat, perasaan, ataupun kepercayaan tentang perilaku diri sendiri maupun perilaku orang lain di lingkungan sosialnya. Unsur kognisi yang nantinya akan menjadi pedoman bagi ODHA dalam berperilaku dan bertindak dengan lingkungan sosialnya. Untuk mengurangi keadaan disonansi, maka seseorang akan melakukan tindakan untuk mengurangi ketidaknyamanan tersebut. ODHA akan cenderung mengembangkan disonansi kognitif ketika interaksinya di lingkungan sosial tidak sesuai dengan harapannya.

\section{METODE PENELITIAN}

Penelitian ini menggunakan penelitian kualitatif dengan metode studi kasus. Kriyantono (2014) menyatakan penelitian kualitatif bertujuan untuk menjelaskan kasus dengan sedalamdalamnya melalui pengumpulan data sedalam-dalamnya. Penelitian kualitatif lebih menekan pada persoalanan kedalaman (kualitas) data bukan banyaknya (kuantitas) data.

Metode yang dipilih adalah metode studi kasus dengan harapan dapat menjelaskan temuan-temuan di lapangan secara lebih mendalam dan intensif. Dikutip dari Arikunto (2010) bahwa metode studi kasus sebagai salah satu jenis pendekatan deskriptif dimana penelitian yang dilakukan secara intensif, terperinci dan mendalam terhadap suatu organisasi, lembaga atau gejala tertentu dengan daerah atau subjek yang sempit.

Subjek penelitian dalam penelitian ini yaitu ODHA sebanyak 4 orang dan informan tambahan yaitu teman, keluarga, konselor, perawat, dan masyarakat yang mampu memberikan informasi dan bersedia meluangkan waktunya saat proses wawancara dengan menggunakan teknik purposive. Nama informan pada penelitian ini diinisialkan demi menjaga kerahasiaan infomasi. Adapun untuk lebih memudahkan dalam mencari subjek, maka 
peneliti mengklasifikasikan karakteristik dan ciri-ciri subjek penelitian sebagai berikut: ODHA telah dinyatakan HIV positif oleh dokter di RSUP H. Adam Malik; ODHA warga negara Indonesia dengan usia 25 49 tahun; ODHA telah terinfeksi HIV/AIDS minimal selama 1 tahun.

Pada penelitian ini pengumpulan data dilakukan dengan menggunakan 2 metode sumber data primer dan sekunder yaitu wawancara mendalam, observasi, kepustakaan, dan dokumentasi.

Proses triangulasi dilakukan terus menerus sepanjang proses mengumpulkan data dan menganalisis data sampai peneliti yakin bahwa sudah tidak ada lagi perbedaan-perbedaan dan tidak ada lagi yang perlu dikonfirmasi kepada informan.

Peneliti dalam hal ini melakukan triangulasi data kepada informan tambahan yaitu teman, keluarga, konselor, perawat, dan masyarakat sekitar RS. Adam Malik. Validitas data dalam penelitian ini menggunakan metode triangulasi sumber, yakni peneliti mencoba mengeksplorasi dan memeriksa kembali derajat kepercayaan suatu informasi yang diperoleh dari hasil wawancara, pengamatan, dan informan tambahan.

\section{HASIL DAN PEMBAHASAN}

Stigma terhadap ODHA adalah persoalan yang menyakitkan hati dan membuat mereka kecewa karena di label negatif oleh lingkungan sosialnya. Stigma yang menganggap bahwa mereka memiliki penyakit tersebut akibat perbuatan yang tidak bermoral dan menyimpang dari norma-norma di masyarakat seperti perilaku seksualitas, berganti pasangan, dan menggunakan narkoba. Begitu juga dengan diskriminasi yang dialami ODHA, sebab mereka diperlakukan berbeda dan tidak sewajarnya seperti diusir, dijauhi, membedakan peralatan makanan, ditolak pada pelayanan kesehatan, dan diskriminasi secara verbal berupa sindiran dan hinaan.

Hal ini juga diungkapkan Indriani dan Fauziah (2017) dimana ODHA mengalami stigma dan diskriminasi dalam keluarga dengan cara menghindar dan berwudhu setelah berinteraksi dengan ODHA, perilaku berupa pemisahan alat makan dan mencuci pakaian. Selain itu, ODHA juga mengalami perilaku yang tidak menyenangkan saat mengakses ARV di rumah sakit dengan cara dibentak-bentak oleh petugas layanan kesehatan dan adanya pernghindaran interaksi secara langsung yang dilakukan rekan kerja ODHA.

ODHA akan memandang dirinya tergantung dari konsep diri yang melekat pada dirinya. Konsep diri juga akan mendorong terjadinya keterbukaan dalam 
hal pengungkapan dirinya di lingkungan sosial. Pengungkapan diri atau self disclosure merupakan pengungkapkan informasi maupun perasaan mengenai diri pribadi yang sebenarnya kepada orang lain. Salah satu model untuk memahami tingkat kesadaran dan pengungkapan diri dalam komunikasi adalah Jendela Johari (Uohari Window).

Josept Luft dan Harrington Ingham (dalam Mulyana, 2005) memberi penjelasan bahwa Jendela Johari mengibaratkan diri manusia sebagai sebuah ruangan yang terdiri dari empat bingkai, dimana masing-masing bingkai menunjukkan daerah diri pribadi. Hasil temuan menunjukkan bahwa keempat informan memiliki 2 bingkai yang mereka lakukan ketika berkomunikasi dengan lingkungan sosialnya, yaitu daerah terbuka dan daerah tersembunyi.

Daerah terbuka menunjukkan keterbukaan ODHA mengenai status kesehatannya terhadap orang lain yaitu keluarga, teman dan petugas kesehatan. Seperti yang diungkapkan salah satu informan $\mathrm{TH}$ yang mengungkap diri kepada keluarganya:

"Saya terbuka kepada keluarga saya, orang tua dan adik saya. Begitu saya keluar dari rumah sakit, mereka langsung saya beritahu, tidak ada yang saya tutup-tutupi. Mereka mendukung saya terutama kedua orangtua saya selalu memberikan semangat untuk terus sehat dan tidak lupa minum obat."

Keterbukaan tersebut disebabkan karena adanya rasa aman dan percaya. Kepercayaan adalah kunci dalam menjalin hubungan yang akrab. Keterbukaan dilakukan sebagai dasar untuk menjalin hubungan antarpribadi yang lebih intim dan mengurangi rasa kekhawatiran yang juga bertujuan agar ODHA menemukan orang-orang yang dapat mendukung mereka bahkan setelah mengetahui kondisi mereka. Hal itu dirasakan oleh ODHA seperti keluarga dan teman terdekat yang selalu mengingatkan dan memotivasi ODHA untuk menjaga kesehatan.

Bingkai kedua adalah daerah tersembunyi yang menunjukkan keadaan dimana ODHA mengetahui hal mengenai dirinya, namun orang lain tidak mengetahui hal tersebut. Daerah ini dilakukan keempat informan kepada lingkungan disekitarnya dengan menyembunyikan status diri mereka di masyarakat. Keempat informan menjaga jarak dengan orang-orang di sekitarnya sehingga hubungan yang terjalin tidak terlalu akrab. Hal ini diungkapkan oleh informan CLMPS yang mengatakan:

"Saya tertutup dan menjaga jarak bahkan bisa disebut jarang berkomunikasi, sehingga tetangga tidak mengetahui status 
saya. Saya selalu berusaha menutupi penyakit saya dari masyarakat."

Keempat informan merasa bahwa jika mereka terbuka dan membangun hubungan akrab dengan masyarakat mereka tidak mendapat sebuah penghargaan dan hanya akan menimbulkan resiko jika lingkungan masyarakat mengetahui status mereka.

Pengungkapan diri ODHA tergantung pada situasi dan orang yang diajak untuk berkomunikasi. Jika orang yang diajak berkomunikasi membuat merasa nyaman serta dapat membangkitkan semangat maka kemungkinan ODHA untuk membuka diri sangatlah besar. Sebaliknya ODHA akan menutup diri dengan lingkungan yang belum bisa menerima dirinya.

Keempat informan mempunyai komunikasi antarpribadi yang berbedabeda dalam menghadapi stigma dan diskriminasi yang mereka terima di lingkungan sosialnya. Informan SBH yang awalnya mendapat penolakan hingga di usir oleh keluarga dan masyarakat membuatnya tampil beda dan percaya diri dengan merubah penampilan, merawat tubuh dan wajah agar tidak terlihat seperti orang yang terinfeksi HIV/AIDS. Informan TH yang memiliki sifat terbuka dan bersikap ramah menjadi awal mula yang baik untuk menjalin komunikasi yang lebih akrab dengan petugas layanan kesehatan yang pernah menstigma dan mendiskriminasi dirinya dengan jibiran dan raut wajah yang kurang menyenangkan. Begitu halnya CLMPS yang di usir dan tidak dianggap keluarga terus berusaha melakukan pendekatan walaupun pada akhirnya hanya orang tua laki-laki yang mau menerima. Berbeda dengan informan $\mathrm{AH}$ yang pernah mendapatkan penolakan dari pelayanan kesehatan dan dijauhi saudaranya lebih memilih untuk menutup diri dan mengindari komunikasi dengan orang lain. Berdasarkan teori tindakan beralasan/Theory of Reasoned Action, Individu akan mempertimbangkan akibat dari tindakannya, latar belakang apa yang membentuk sikap dan tingkah lakunya ketika melakukan suatu hal dan atas dasar alasan apa dalam bertindak. ODHA juga akan mempertimbangkan dan memiliki penilaian tersendiri mengenai tindakan yang ia lakukan kepada orang lain akan berakibat buruk atau tidak kepada dirinya. Hambatan komunikasi pada dasarnya dapat dibedakan atas tujuh macam, diantaranya hambatan teknis, hambatan sematik dan psikologi, hambatan fisik, hambatan status, hambatan kerangka berfikir serta hambatan yang disebabkan perbedaan budaya (Cangara, 2009:153). Hambatan tersebut tentu dapat membuat 
komunikasi menjadi tidak efektif sehingga mempengaruhi komunikasi antarpribadi ODHA.

Temuan penelitian menunjukkan bahwa terdapat tiga hambatan yang dialami ODHA ketika berkomunikasi dengan lingkungan sosial diantaranya yaitu, hambatan kerangka berfikir atau kognitif, dimana lingkungan sosial memiliki persepsi yang berbeda tentang HIV/AIDS karena kurangnya pengetahuan mengenai hal tersebut yang bisa menimbulkan terjadinya stigma dan diskriminasi. Hal ini didukung pernyataan perawat sebagai berikut:

"Penyakit ini dianggap masyarakat adalah penyakit yang memalukan dan mematikan. Biasanya mereka kurang paham informasi mengenai HIV/AIDS. Terlebih orang menganggap bahwa penderita HIV pasti akan meninggal dan mengakibatkan infeksi segala macam penyakit. Sehingga masyarakat takut berdekatan dengan penderita. Mereka juga beranggapan bahwa HIV/AIDS disebabkan karena perilaku yang kurang bagus."

Selanjutnya hambatan psikologis, disebabkan adanya persoalan dalam diri ODHA meliputi ketidaksiapan menerima status sebagai ODHA, ketakutan jika orang lain mengetahui statusnya, dipecat dari lingkungan kerja sehingga tidak memiliki pekerjaan, dan terkait masalah stigma dan diskriminasi yang diterima ODHA.

Kemudian hambatan fisik, yaitu ODHA yang sudah terinfeksi TB (Tuberkulosis) akan sulit berkomunikasi dengan orang lain. Hal ini diungkapkan informan $\mathrm{AH}$ dimana ia mengalami kesulitan karena harus selalu memakai masker.

Berkaitan dengan teori disonansi kognitif yang menjelaskan perilaku berdasarkan keinginan antara sikap dan prilaku yang dipegang seseorang, adanya perasaan yang tidak sesuai dengan apa yang mereka yakini akibat adanya hambatan selama komunikasi berlangsung. Pada saat berkomunikasi seseorang memiliki batas yang didasarkan pada pertimbangan dan pikiran seseorang. Komunikasi yang dilakukan ODHA dengan cara menutupi status kesehatannya untuk memperoleh harga dirinya di lingkungan sekitarnya yang bertujuan agar terhindar dari stigma dan diskriminasi.

Perlu adanya model interaksi sebagai bentuk arah komunikasi yang menggambarkan penerapan teori untuk kasus-kasus tertentu sehingga tersusun kerangka konseptual yang memperlihatkan kaitan antara satu komponen komunikasi dengan komponen lainnya. Penerapan model komunikasi dapat dilihat salah satunya melalui model 
komunikasi antarpribadi oleh Devito, dimana suatu proses komunikasi antarpribadi terjadi ketika sumber atau pengirim (source/encoder) mengirimkan pesan (messages) dalam bentuk verbal atau nonverbal melalui suatu saluran (channels) kepada penerima (receiver/decoder) yang dapat memberikan umpan balik (feedback) ataupun umpan maju (feedforward). Pada proses pengiriman pesan maupun umpan balik, terdapat gangguan (noise) yang dapat merusak atau merubah isi pesan yang dikirimkan sesuai dengan situasi, konteks (lingkungan fisik, sosiopsikologis, dan budaya), maupun hubungan antar pelaku komunikasi yang dapat berefek pada kognitif, afektif, dan perilaku penerima atau sumber (Devito, 2017).

Berdasarkan model komunikasi antarpribadi Devito, peneliti mencoba menggambarkan sebuah model komunikasi yang dilakukan oleh Orang Dengan HIV/AIDS (ODHA) dengan lingkungan sosialnya (keluarga, teman, petugas layanan kesehatan, dan masyarakat) dalam memberikan infomasi statusnya sebagai ODHA yang dapat dilihat pada gambar berikut:

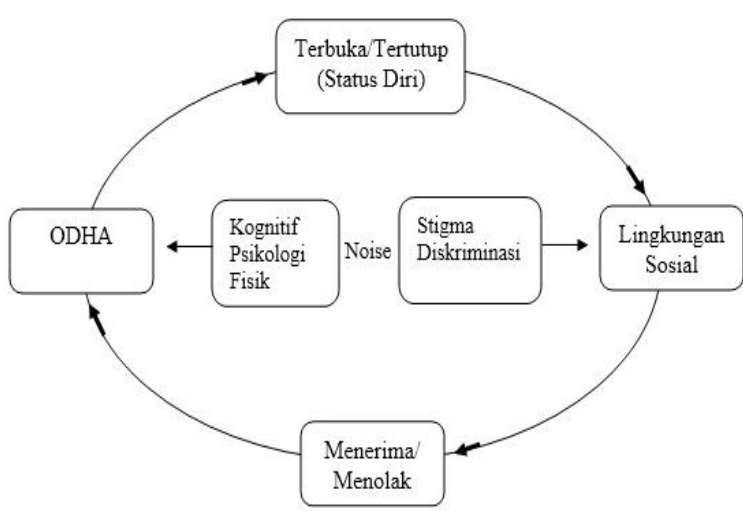

Gambar 1. Model Komunikasi Antarpribadi ODHA Sumber: Olahan Peneliti

Komunikasi Antarpribadi ODHA dalam menyampaikan informasi status dirinya kepada lingkungan sosial dilakukan melalui 2 cara, yaitu dengan terbuka dan tertutup. Dalam proses komunikasi tersebut ODHA sebagai komunikator dipengaruhi oleh faktorfaktor berupa hambatan kognitif, psikologi, dan fisik. Begitu juga dengan lingkungan sosial yang memberikan stigma dan diskriminasi kepada ODHA sehingga mempengaruhi proses penyampaian informasi tersebut yang dapat berefek pada diterima atau ditolaknya mereka di lingkungan sosialnya.

Berkomunikasi perlu menghubungkan antara pengetahuan yang dimiliki masyarakat mengenai HIV/AIDS itu sendiri agar komunikasi berjalan dengan baik. Kurangnya pengetahuan masyarakat tentang HIV/AIDS secara umum, bagaimana cara penularannya, dan adanya pemikiran masyarakat yang masih mengaitkan bahwa HIV/AIDS dilakukan 
karena perilaku yang tidak sesuai normanorma yang berlaku di masyarakat sehingga memungkinkan terjadinya stigma dan diskriminasi yang masih tinggi.

Komunikasi antarpribadi yang dilakukan ODHA tergantung dengan siapa yang diajak untuk berkomunikasi, termasuk hubungan kedekatan dengan lawan bicara mereka. Adanya persoalan psikologis dalam diri ODHA dan kondisi fisik yang juga dapat mempengaruhi komunikasi tersebut, dimana masih ada pemikiran dan perasaan takut akan dijauhi jika identitasnya sebagai ODHA diketahui orang lain. Hal-hal tersebut dapat diterapkan ODHA melalui model komunikasi dengan menyesuaikan kondisi dimana komunikasi itu terjadi di lingkungan sosial tempat ODHA berada.

Pertama, dengan terbuka tentang kondisi kesehatannya. Mereka adalah ODHA yang mendapatkan dukungan dari orang-orang terdekat dan memiliki konsep diri yang positif untuk memulai keterbukaan serta didasarkan untuk pengambilan obat ARV dan pemeriksaan kondisi kesehatan kepada petugas layanan kesehatan.

Kedua dengan cara tertutup yaitu menyembunyikan statusnya sebagai ODHA dikarenakan masyarakat belum memiliki pemahaman yang sebenarnya mengenai HIV/AIDS dan masih dikaitkan terhadap norma-norma sosial di masyarakat. ODHA berusaha menyembunyikan status diri akibat adanya rasa takut tidak diterima oleh masyarakat yang dapat berakibat buruk bagi dirinya. Selain itu adanya pertimbangan dari ODHA itu sendiri untuk melindungi dan menjaga nama baik keluarga yang juga bisa berdampak mendapatkan stigma dan diskriminasi, seperti ungkapan informan SBH:

"Saya belum berani terbuka karena ibu mertua berpesan untuk tidak terlalu membuka diri karena ia juga menyampaikan bagaimana lelahnya menyembunyikan status suami saya yang juga ODHA. Saya ingin menjaga nama baik keluarga suami saya."

Jika lingkungan sosial tidak mau menerima mereka, maka ODHA memilih untuk menutup diri. Adanya ketidakmampuan keempat informan dalam membuka diri secara terbuka kepada masyarakat dengan cara menjaga jarak, menghindari berkomunikasi, dan bersikap wajar seperti yang dilakukan keempat informan kepada lingkungan sekitar mereka.

\section{SIMPULAN}

Komunikasi antarpribadi ODHA dalam menyampaikan informasi status diri masih memperoleh stigma dan diskriminasi dari lingkungan sosial berupa penolakan, pengusiran, pengucilan, jibiran, 
dan ekspresi wajah yang kurang menyenangkan. SBH yang mendapat penolakan dari keluarga memilih untuk merubah penampilan agar tidak terlihat seperti orang yang terinfeksi HIV/AIDS. Begitu juga CLMPS yang terus melakukan pendekatan kepada keluarga. TH bersikap ramah kepada petugas layanan kesehatan demi mendapatkan obat untuk anaknya. Sedangkan AH lebih memilih untuk menutup diri dan mengindari komunikasi dengan orang lain. Komunikasi keempat informan di masyarakat pada umumnya sama yaitu masih menyembunyikan status diri sebagai ODHA dengan bersikap secara wajar, menjaga jarak, dan berbohong tentang penyakitnya. Hambatan komunikasi yang dialami ODHA yaitu hambatan kognitif, dimana lingkungan sosial memiliki persepsi yang berbeda tentang HIV/AIDS karena kurangnya pengetahuan mengenai hal tersebut dan masih dikaitkan dengan moralitas. Hambatan psikologis, dimana hambatan ini disebabkan oleh persoalan dalam diri ODHA. Kemudian hambatan fisik, yaitu ODHA yang sudah terinfeksi TB (Tuberkulosis) akan sulit berkomunikasi dengan orang lain. Model komunikasi antarpribadi yang dilakukan ODHA dalam menyampaikan informasi status dirinya di lingkungan sosial dilakukan melalui 2 cara, yaitu dengan terbuka dan tertutup.
Terbuka dengan memberikan informasi tentang kondisi kesehatannya. Selanjutnya dengan tertutup yaitu menyembunyikan status dirinya sebagai ODHA yang bertujuan agar terhindar dari stigma dan diskriminasi di masyarakat.

\section{DAFTAR PUSTAKA}

Arikunto, S. (2010). Prosedur Penelitian Suatu Pendekatan Praktik. Jakarta: Rineka Cipta.

Bungin, B. (2013). Sosiologi Komunikasi: Teori, Paradigma, dan Discourse Teknologi Komunikasi di Masyarakat. Jakarta: Kencana Prenada Media Group.

Cangara, H. (2009). Pengantar Ilmu Komunikasi. Jakarta: Rajawali Pers.

Devito, J.A. (2017). The Interpersonal Communication Book Fifteenth Edition. Boston: Pearson Education.

Effendy, O.U. (2003). Ilmu, Teori dan Filsafat Komunikasi. Bandung: Citra Aditya Bakti.

Gaudine, A. Gien, L. Thuan, T.T. and Dung, D.V. (2010). Perspectives of HIV-related stigma in a community in Vietnam: A qualitative Study. International Journal of Nursing Studies, 47: 38-48.

Hutagalung, I. (2015). Teori-Teori Komunikasi dalam Pengaruh Psikologi. Jakarta: Indeks.

Indriani, S.D. \& Fauziah, N. (2017). Karena Hidup Harus Terus Berjalan (Sebuah Studi Fenomenologi Kehidupan Orang dengan HIV/AIDS). Jurnal Empati. Januari 2017, Volume 6(1), 385-395.

Jogiyanto. (2007). Sistem Informasi Keperilakuan Edisi revisi. Yogyakarta: Andi Offset.

Kementerian Kesehatan Republik Indonesia. (2017). Laporan Perkembangan HIV-AIDS \& Penyakit Infeksi Menular Seksual (PIMS) Triwulan I Tahun 2017. Jakarta: Kemenkes RI.

Keputusan Menteri Kesehatan RI No 782/Menkes/SK/IV/2011 Tentang Rumah Sakit Rujukan Bagi ODHA.

Kriyantono, R. (2014). Teknik Praktis Riset Komunikasi. Jakarta: Kencana Prenada Media.

Liputan6. (2016). Kisah 2 ODHA yang Menyentuh Hati. Diunduh di http://health.liputan6.com/read/2667535/ kisah-2-odha-yang-menyentuh-hati tanggal 20 Juni 2017. 
Littlejohn, S.W. \& Foss, K.A. (2011). Teori Komunikasi: Theories of Human Communication. Jakarta: Salemba Humanika.

Miller, K. (2001). Communication Theories: Perspectives, Processes, and Contexts. New York: McGraw Hill.

Mulyana, D. (2005). Human Communication: Konteks-Konteks Komunikasi. Bandung: Remaja Rosdakarya.

(2006). Ilmu Komunikasi Suatu Pengantar. Bandung: Remaja Rosdakarya.

Peraturan Daerah Kota Medan No. 01 Tahun 2012 tentang Pencegahan dan Penanggulangan HIV dan AIDS.
Roey, J.V. (2003). From Principle to Practice: Greater Involvement of People Living with or Affected by HIV/AIDS (GIPA). (Yayasan Spiritia, Terjemahan). Jakarta: Yayasan Spiritia.

Sarwono, W.S. (2004). Psikologi Remaja. Jakarta: Raja Grafindo Persada.

Suriana, A. \& Dewi, D.S.E. (2013). Penelitian Tentang Self Disclosure Pasien ODHA RSUD Banyumas. Journal Psycho Idea. Tahun 11 No. 1, ISSN 1693-1076. Februari 2013.

Surip, M. (2011). Teori Komunikasi Perspektif Teoritis Teori Komunikasi. Medan: UNIMED.

Wood, J.T. (2013). Komunikasi Teori dan Praktik: Komunikasi dalam kehidupan Kita. Jakarta: Salemba Humanika. 